\title{
The Human Alveolar Macrophage: Isolation, Cultivation in Vitro, and Studies of
} Morphologic and Functional Characteristics

\author{
Allen B. Cohen and Martin J. Cline \\ From the Cardiovascular Research Institute and the Cancer Research Institute, \\ Department of Medicine, University of California, San Francisco, California 94122
}

A B S T R A C T Human alveolar macrophages were lavaged from surgically resected lungs and from lungs of normal subjects. Macrophages that had been purified by glass adherence were maintained in tissue culture for as long as 54 days. After 3-4 wk in vitro they underwent transformation into multinucleated giant cells. These aged cells had more than 30 times the phagocytic capacity that the same group of cells had had after 1 day in vitro.

Phagocytosis of heat-killed Candida albicans was inhibited by iodoacetate, sodium fluoride, potassium cyanide, and low partial pressures of oxygen, suggesting that these cells require both oxidative and glycolytic energy sources for maximal particle ingestion. Alveolar macrophages and monocyte-derived macrophages killed Listeria monocytogenes with similar efficiency, but neutrophils were more efficient than either of the other cell types. Bacterial killing is probably not dependent upon myeloperoxidase in the monocyte-derived macrophage or in the alveolar macrophage since histochemical stains for peroxidase do not stain either cell type. C. albicans blastospores, which are killed by neutrophils and monocytes that contain myeloperoxidase, were not killed by human alveolar macrophages during the $4 \mathrm{hr}$ of observation.

Large cells with supernormal phagocytic capacity were recovered from patients with postobstructive pheumonia and from one patient with recurrent bacterial pneumonia, indicating that macrophage function can be altered in certain disease states.

Human alveolar macrophages are unique human phagocytes in their dependence on an oxygen tension greater than $25 \mathrm{~mm} \mathrm{HG}$ for maximal phagocytosis. Carbon dioxide tensions as high as $70 \mathrm{~mm} \mathrm{Hg}$ did not alter phago-

Received for publication 30 September 1970 and in revised form 19 January 1971. cytosis when the $\mathrm{pH}$ of the medium was held constant. These data suggest that the increased susceptibility to pneumonia of patients with chronic bronchitis or atelectasis may be in part related to suboptimal phagocytosis by macrophages in areas of the lung with depressed oxygen tension.

\section{INTRODUCTION}

The alveolar macrophage of a variety of species has been implicated as the most imporant mechanism by which the lungs are protected from aerosols of microorganisms (1-4). To our knowledge, however, only one study of the function of human alveolar macrophages has been published (5).

In 1961 Myrvik, Leake, and Fariss (6) developed a method of obtaining rabbit alveolar macrophages by transtracheal lavage after removal of the heart and lungs. Voisin, Guillaume, Van-Moorleghem, and Aerts (7) maintained guinea pig alveolar macrophages in tissue culture for as long as 2 wk in order to study their changing phagocytic and metabolic characteristics. In 1967 Finley, Swenson, Curran, Huber, and Ladman (8) devised a method for washing alveolar macrophages from human subjects, and subsequently Pratt, Finley, Smith, and Ladman (9) reported electron microscopic studies of cells retrieved by this technique. The method, however, was found to be unsuitable for use in patients with abnormal lung function, and the number of cells recovered was too small to allow large-scale studies. We therefore developed a method for retrieving alveolar macrophages from surgically removed human lungs. Alveolar macrophages obtained by this method and by the method of Finley (8) were maintained in tissue culture for prolonged periods. The long-term in vitro survival of cells obtained from the surgical specimens has enabled us to study the metabolic requirements for 
phagocytosis, the capacity of the cells to kill bacteria, and the function of the cells in certain disease states.

\section{METHODS}

Cell retrieval. The age, lung disease (if present) and smoking status of donors of the macrophages are given in Table I.

Cells were recovered from surgically removed lungs as follows: a balloon-tipped catheter was placed into the largest available bronchus under aseptic conditions. Hanks' balanced salt solution containing $10 \%$ fetal calf serum, 10 units of heparin per $\mathrm{ml}, 50$ units of penicillin per $\mathrm{ml}$, and $50 \mu \mathrm{g}$ of streptomycin per $\mathrm{ml}$ (fetal calf serum-Hanks) was injected repeatedly into the lung with a $50-\mathrm{ml}$ syringe until $50-\mathrm{ml}$ volumes of medium could be recovered by gravity-drainage or by aspiration for each $50 \mathrm{ml}$ injected.

Cells were retrieved from the lungs of awake, normal volunteers by the method of Finley (8). Briefly, a No. 19 Metras catheter was placed into a segmental bronchus under fluoroscopic control. The balloon surrounding the catheter was inflated and the cells were retrieved by lavaging the segment of lung with three $100-\mathrm{ml}$ portions of $0.9 \%$ saline. The aspirated solution was added to an equal volume of fetal calf serum-Hanks.

Cells retrieved by either method were centrifuged at room temperature at $125 \mathrm{~g}$ for $10 \mathrm{~min}$, suspended in a small volume of fetal calf serum-Hanks, and centrifuged again at the same speed. Viability was assessed by exclusion of $0.5 \%$ Trypan Blue dye. The cell pellet was then suspended at $10^{\circ}$ viable macrophages per $\mathrm{ml}$ in McCoy's $5 \mathrm{~A}$ medium (Grand Island Biological Co.) with $30 \%$ human AB serum, and 1-ml volumes were distributed into Leighton tubes (Bellco Glass, Inc.) containing cover slips. This medium was used in all subsequent experiments. All of the macrophages that would adhere had done so by $4 \mathrm{hr}$. Cells washedoff after $4 \mathrm{hr}$ failed to adhere to another glass surface and did not phagocytize heat-killed $C$. albicans in suspension cultures.

Morphology. Cells pelleted on glass slides with a cytocentrifuge (Shandon Scientific Co., London) and cells adhering to cover slips were fixed in $100 \%$ methanol and stained with Giemsa. Viable cells were observed by phase contrast microscopy, and freshly obtained unfixed cells were stained for peroxidase by the method of Goodpasture as modified by Beacom (10).

Minimum and maximum cell diameters were measured with a micrometer eyepiece, and the cell area was calculated using the formula for area of an ellipse.

Cells viewed with the electron microscope were prepared for examination immediately after retrieval or after they had been allowed to adhere to Melinex plastic cover slips (Imperial Chemical Industries, New York) in Leighton tubes for different periods. Cells from the initial cell suspensions were centrifuged at $250 \mathrm{~g}$ for $10 \mathrm{~min}$, fixed at $4^{\circ} \mathrm{C}$ overnight in $3 \%$ distilled glutaraldehyde, buffered to 7.4 with $0.1 \mathrm{M}$ sodium cacodylate, and postfixed with $1 \%$ osmium tetroxide. Dehydration, embedding, and sectioning were accomplished by standard methods (11). Sections were examined with a Siemen's Elmiskop IA electron microscope (Siemens America, Inc, New York). Macrophages adhering to the Melinex plastic film were processed by the method of Firket (12).

Phagocytosis. In all phagocytosis experiments, $3 \times 10^{7}$ heat-killed $C$. albicans cells (or Aspergillus fumigatus spores) were added in $0.1 \mathrm{ml}$ volume to each of two
TABLE I

Source of Alveolar Macrophages

\begin{tabular}{|c|c|c|c|}
\hline & $\begin{array}{c}\text { Non- } \\
\text { smokers }\end{array}$ & $\begin{array}{l}\text { Tobacco } \\
\text { smokers }\end{array}$ & $\begin{array}{l}\text { Marijuana } \\
\text { smokers }\end{array}$ \\
\hline \multicolumn{4}{|l|}{ Donors } \\
\hline $\begin{array}{l}\text { Average age, yr } \\
\text { Cigarettes smoked }\end{array}$ & 56.0 & 52.1 & 25.0 \\
\hline $\begin{array}{l}\text { per day (average) } \\
\text { (Range) }\end{array}$ & - & $\begin{array}{l}10-60 \\
(36)\end{array}$ & $\begin{array}{l}3-20 \\
(6)\end{array}$ \\
\hline \multicolumn{4}{|l|}{ Type of lavage } \\
\hline Finley method & 3 & 2 & 7 \\
\hline Resected lung & & & \\
\hline $\begin{array}{l}\text { Benign tumor of } \\
\text { bronchus }\end{array}$ & $\begin{array}{l}2 \\
(1)^{*}\end{array}$ & 一 & - \\
\hline $\begin{array}{l}\text { Malignant tumor of } \\
\text { bronchus }\end{array}$ & 6 & $\begin{array}{l}11 \\
(2)^{*}\end{array}$ & 一 \\
\hline Aspergilloma & - & 1 & - \\
\hline
\end{tabular}

* Number of patients with postobstructive pneumonia.

Leighton tubes containing alveolar macrophages. After incubation at $37^{\circ} \mathrm{C}$, the cover slips were retrieved, washed in warm medium, fixed, and stained. The number of $C$. albicans was counted in 25 cells in each quadrant of each cover slip. The results are expressed as the number of $C$. albicans taken up by 100 macrophages.

Inhibition of phagocytosis. Experiments were carried out on cells within $1 \mathrm{wk}$ after isolation. Sodium iodoacetate $\left(1 \times 10^{-4} \mathrm{M}\right)$, sodium fluoride $\left(2 \times 10^{-8} \mathrm{M}\right)$, potassium cyanide $\left(1 \times 10^{-8} \mathrm{M}\right)$, or 2,4-dinitrophenol $\left(2 \times 10^{-4} \mathrm{M}\right)$ were each incubated with macrophages for $1 \mathrm{hr}$. $C$. albicans blastospores were then added to the control and treated tubes, and the phagocytosis experiment was carried out as described.

The effect of iodoacetate, cyanide, and 2,4-dinitrophenol on the rate of oxygen consumption by the cells was measured with a Gilson Oxygraph (Gilson Medical Electronics, Inc, Middleton, Wis.).

The effect of high carbon dioxide and low or absent oxygen concentration on phagocytosis was determined similarly. The gas and $C$. albicans were added through needles in the tops of the tubes so that the gas environment of the cells was not disturbed during the experiment. All gases were warmed to $37^{\circ} \mathrm{C}$ and humidified before they were passed over cells. $\mathrm{PH}$ was held constant by adding sodium bicarbonate to the medium. Control tubes were equilibrated with $5 \%$ carbon dioxide in air. The gas tension and $\mathrm{pH}$ of the fluid bathing the cells were measured after each experiment. Phagocytosis was allowed to proceed for $30 \mathrm{~min}$.

Bacterial killing experiments. The ability of alveolar macrophages, polymorphonuclear leukocytes, and monocytes to kill Listeria monocytogenes or Klebsiella pneumoniae type I was tested by a previously described method (13). Bacteria were incubated for approximately $18 \mathrm{hr}$ in trypticase soy broth containing methionine labeled with ${ }^{75} \mathrm{Se}$, or ${ }^{32} \mathrm{P}$. labeled sodium phosphate, then washed 7 times to remove free radioactivity. Bacterial concentration was determined by measuring optical density at $620 \mathrm{~m} \mu$. Approximately 3$7 \times 10^{7}$ organisms were added to each Leighton tube at the 


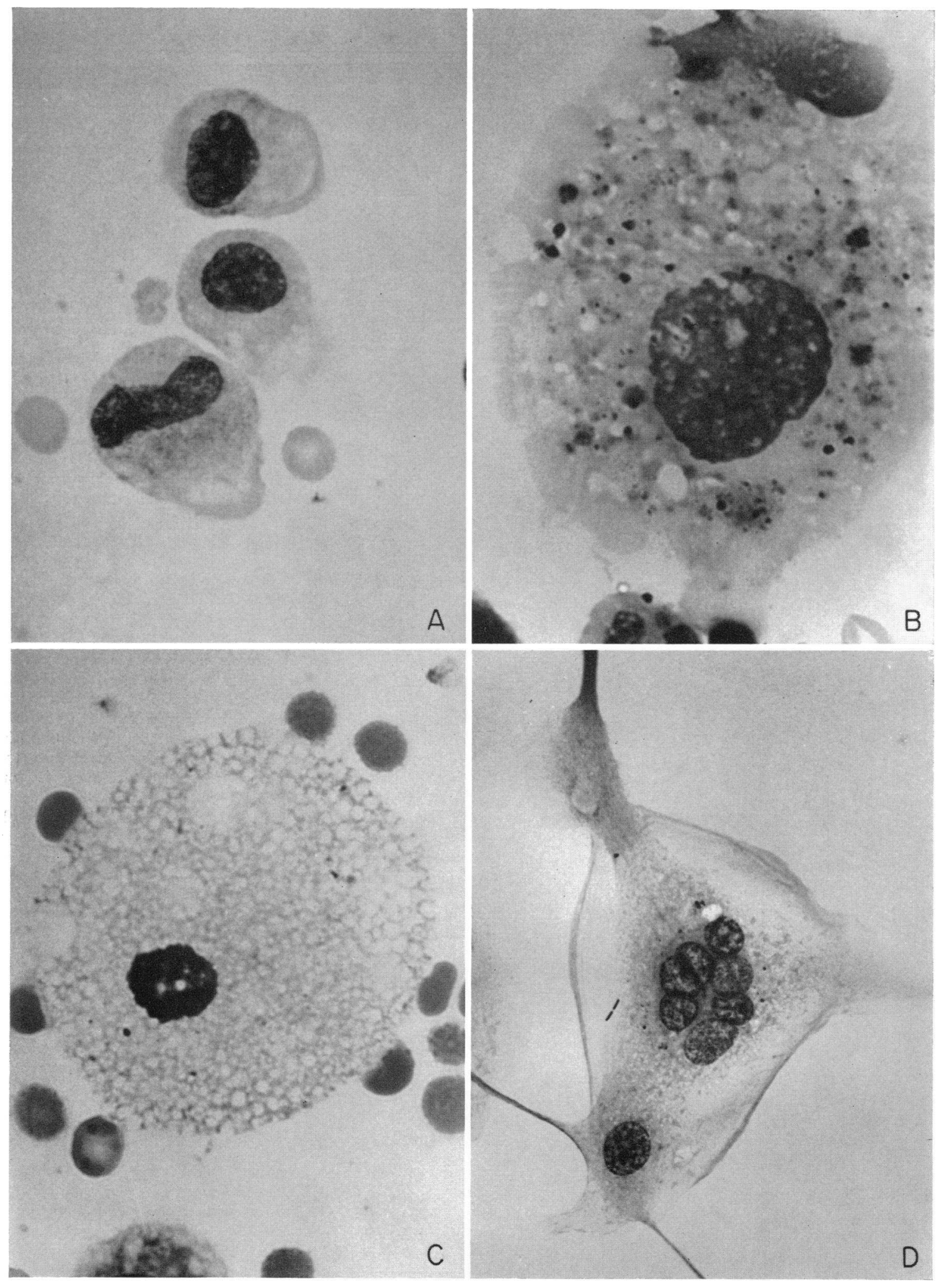


beginning of the experiment. At the end of $90 \mathrm{~min}$ the tubes were washed to remove extracellular bacteria and the remaining bacteria were released from the macrophages into the clean medium by sonication. Viability of released bacteria was assessed by a standard pour-plate dilution method and the number of phagocytized bacteria was determined by counting the radioactivity in the medium with a liquid scintillation spectrometer. The results were expressed as the per cent of phagocytosed bacteria killed. Control tubes containing no macrophages were included to assess the efficiency of the wash-out procedure. Specific activity of the bacteria (number of viable bacteria per count per min) was measured in tubes containing bacteria but no macrophages.

When killing of bacteria beyond the 90 -min phagocytosis period was measured, an antibiotic to kill the few extracellular bacteria was added after the 90 -min wash. At the desired time, the action of the antibiotic was terminated by adding penicillinase (penicillin) or by diluating the antibiotic (streptomycin) to nonbactericidal concentrations.

Candidacidal activity. The ability of the macrophages to kill $C$. albicans was assessed by two methods. In the first method the uptake of methylene blue by phagocytized fungi indicates nonviable organisms (14). The second method assesses morphological changes of intracellular organisms in Giemsa-stained slides (15).

\section{RESULTS}

Retrieval procedure. Lavage of surgical specimens with 1-2 liters of wash solution yielded $0.8 \times 10^{8}-6.0 \times$ $10^{8}$ cells, whereas lavage of the lungs of awake volunteers with $300 \mathrm{ml}$ of wash solution yielded $1.0 \times 10^{6}-$ $8.0 \times 10^{6}$ cells. Pure populations of macrophages could be isolated because other cells in the lavage fluid did not adhere and survive on glass for more than $24 \mathrm{hr}$.

Morphology. Cytocentrifuge preparations were made of cells in suspension soon after they were recovered. From 5 to $35 \%$ of the nonerythrocytic cells were peripheral blood leukocytes and the rest were large, mononuclear cells. Three types of large, mononuclear cells could be distinguished morphologically (Fig. 1); for convenience these cells are termed type A, B, and C for this study. Type A cells (Fig. 1A) accounted for 94-98\% of the mononuclear cells in the lavage fluid from lung tissue which was not distal to an obstructed bronchus. The cells had a mean diameter of $25 \mu$, with a range of $10-45 \mu$. The cytoplasm was stained dark and muddy gray and contained many small, dark blue granules with Giemsa stain but showed no staining with peroxidase stain. The nucleus was oval or irregular and stained dark blue to aqua. Vacuoles were often present, especially at the outer border of the cell. Spontaneous ingestion of autologous red blood cells by viable macrophages was occasionally observed by phase microscopy. Electron micrographs of these cells showed numerous mitochondria and lysosomes and abundant quantities of granular endoplasmic reticulum. Large inclusions were seen, especially in smokers' cells.

About $5 \%$ of the mononuclear cells in the lavage fluid were type $B$. The cells had a mean diameter of $30 \mu$, with a range of $25-40 \mu$. The most easily identifiable difference between type $A$ and $B$ cells was seen in the nucleus. The nucleous of the type $B$ cell was red to pink with Giemsa stain and had a nucleus: cytoplasm ratio of about $1: 6$ or $1: 7$, whereas the type A cell had a nucleus: cytoplasm ratio closer to $1: 3$. The cytoplasm of the type B cell contained fewer granules than the type $\mathrm{A}$ cell and had large, green-staining inclusion bodies (Fig. 1B).

Type $C$ cells accounted for less than $1 \%$ of the mononuclear cells washed from normal lungs but contributed up to $95 \%$ of the macrophages washed from the lungs of the patients with postobstructive endogenous lipoid pneumonia (Fig. 1C). They were the only variety of alveolar macrophage in which phagocytized intact nucleated cells were observed. Their mean diameter was $40 \mu$ and the cytoplasm was packed with vacuoles. When attached to glass, the vacuoles became less prominent or disappeared completely; the cells then looked like macrophages washed from normal lungs.

The population of cells that adhered to glass appeared to be homogeneous and resembled type A cells. Type B cells either did not adhere to glass or phagocytose, or they did adhere but changed their morphologic characteristics after adherence. Type $\mathrm{C}$ macrophages did adhere to glass and phagocytize and probably represented type A cells that had been modified by the environment distal to the obstructed bronchus. Adherent cells transformed into multinucleated, large, vacuolated cells after 3-4 wk in vitro (Fig. 1D). Experiments were performed on cells during the 1 st wk after isolation, except for experiments specifically designed to study latestage cells.

Phagocytosis. Cells were maintained in vitro for as long as $\mathbf{5 4}$ days. The capacity of the cells to ingest heatkilled $C$. albicans in $15 \mathrm{~min}$ increased as the cells aged in vitro (Fig. 2). The increase in phagocytic capacity was proportional to the square root of the area of the cells (Fig. 3) and was therefore directly proportional to length of the cell perimeter.. Uptake of $C$. albicans by cells on the 1st day after isolation was also related to

FIgURE 1 Large mononuclear cells in lavage fluid from human lungs. (A) Type A cell, alveolar macrophage from normal subject; (B) type B cell, differing from type A macrophage in nuclear characteristics and nucleus: cytoplasm ratio; $(C)$ type $C$ cell, predominant phagocytic cell lavaged from area of lung distal to bronchial obstruction; (D) multinucleated giant cell, characteristic appearance of type A cells after they have been maintained 3-4 wk in vitro. $\times 1250$. 


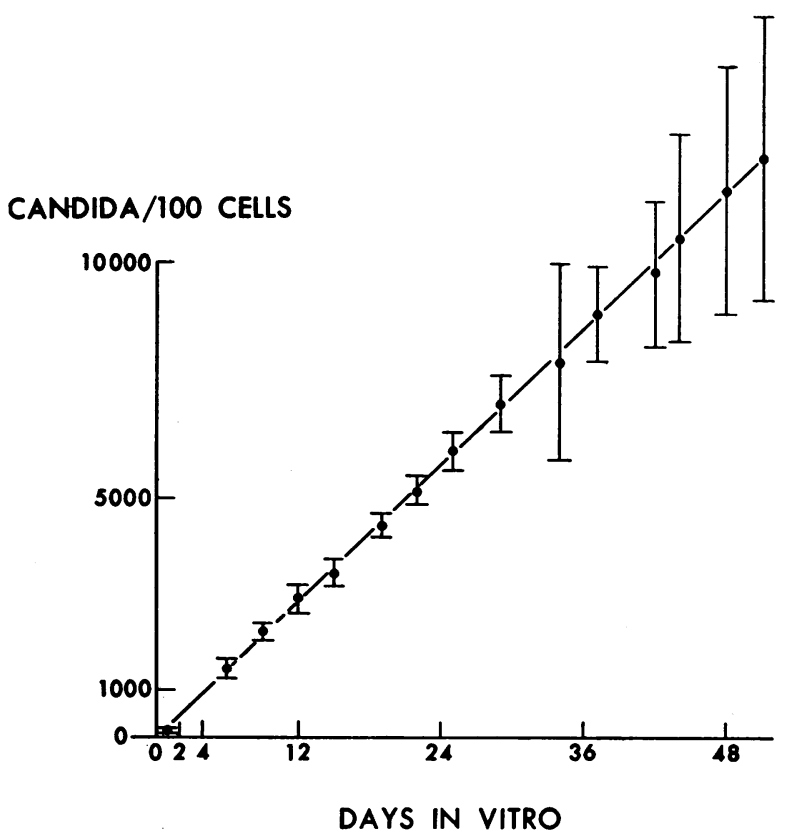

FIGURE 2 Increase in capacity of alveolar macrophages to ingest $C$. albicans with increase in cell age in vitro. Cells were incubated with $10^{7}$ heat-killed $C$. albicans blastospores for $15 \mathrm{~min}$. Increasing the concentration of blastospores did not increase phagocytosis further. The line is the calculated regression line for samples from one individual studied at varied times after isolation. Four similar experiments also showed a linear increase of phagocytosis with cell age. Vertical lines indicate standard errors of the mean.

cell size but rate of change of capacity with measured cell area was greater for these cells than for cells that had been in vitro longer than $1 \mathrm{wk}$. The number of phagocytized particles did not increase when higher concentrations of $C$. albicans were added. On the 1st day after isolation the mean uptake of heat-killed $C$. albicans by alveolar macrophages from nonsmoking subjects was 3.27 C. albicans per cell ( $\mathrm{SE} \pm 0.6$ ) (Fig. 4). Uptake of $C$. albicans by macrophages from smokers of marijuana and tobacco cigarettes was not significantly different from the uptake of normal cells $(P>0.1$ by Student's " $t$ " test). Alveolar macrophages from four patients phagocytized higher numbers of $C$. albicans. The phagocytic capacity of cells from all four patients was outside the $99 \%$ tolerance limits of the phagocytic capacity of the macrophages from the other subjects, but the increased uptake was not greater than predicted for their size (Fig. 3). Three of these subjects had "postobstructive" or "lipoid" pneumonia. The fourth subject, a marijuana smoker, had suffered repeated episodes of pneumonia, most likely from aspiration during his frequent semistuporous periods.

When particle uptake was observed at intervals after the addition of phagocytic particles (either heat-killed
C. albicans or heat-killed $A$. fumigatus), the cell capacity to ingest particles rose to a maximum between 30 and $45 \mathrm{~min}$ and declined thereafter (Fig. 5). The decline after 45 min was caused in part by particle digestion, as judged by the observation of $C$. albicans fragments inside large vacuoles, and in part by loss of particle-laden cells from the cover slips, as judged by the decreasing number of cells per cover slip.

Phagocytosis by these cells was partially opsonin dependent. Studies of phagocytosis of $A$. fumigatus were carried out with normal pooled serum in the culture medium or with serum from two patients with aspergillosis. The serum of both patients contained precipitating antibodies of the IgG class, and one serum also contained skin-sensitizing antibody of the IgE class. (IgG and IgE were demonstrated with specific antisera to each class of antibody.) Phagocytosis of $\mathrm{A}$. fumigatus was greater in 1-day-old cells incubated with either of the two antibody-containing sera (506.6 A. fumigatus $/ 100$ cells \pm SE 55.5 and 911.4 A. fumigatus $/ 100$ cells \pm SE 51.1, respectively) than in the cells incubated with the normal serum (162 A. fumigatus per 100 cells $\pm \mathrm{SE}$ 11.6). These differences were significant at the $0.1 \%$ level for both sera. Phagocytosis of $C$. albicans was not increased by these two sera.

The rate of oxygen consumption was measured before and after the addition of inhibitors or after the addition of $C$. albicans in two experiments on two different

\section{CANDIDA/100 CELLS}

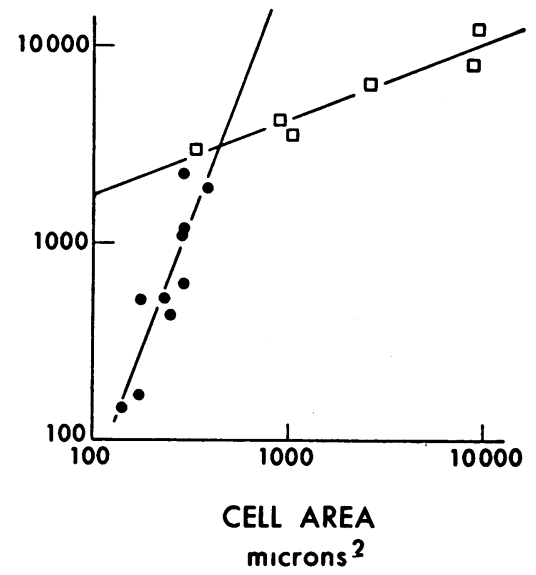

FIgURE 3 Phagocytosis with size. C. albicans uptake and the length of and major and minor axes of cells were measured on the same coverslips. Areas were calculated using the formula for an ellipse. Open squares represent studies on cell populations from two individuals measured from 7 to 54 days after isolation (correlation coefficient $r=0.957$ ). Each closed circle represents a different subject studied on the first day after isolation (correlation coefficient $r=0.879$ ). The upper four points represent cells from patients with postobstructive pneumonia. Lines are calculated regression lines. Points are plotted on a log log scale. 
groups of cells. Sodium iodoacetate, $1 \times 10^{-4} \mathrm{M}$, did not change the rate of resting oxygen consumption of the cells. Potassium cyanide, $1 \times 10^{-8} \mathrm{M}$, reduced the rate of oxygen consumption to levels too low to be measured by the Oxygraph. At this concentration of cyanide the cells were still able to exclude Trypan Blue dye. The addition of 2,4-dinitrophenol, $2 \times 10^{-4} \mathrm{M}$, increased the rate of oxygen consumption 4-fold. No increase was observed after addition of $C$. albicans. Phagocytosis was studied after exposure of the cells to metabolic inhibitors before adding the test particles. Partial inhibition of phagocytosis was demonstrated when glycolysis, cytochrome electron transport, or total oxidative metabolism was inhibited (Table II).

The effect of high carbon dioxide and low oxygen tensions on phagocytosis is shown in Table III. Phagocytosis was inhibited by an oxygen tension of $25 \mathrm{~mm} \mathrm{Hg}$. No greater inhibition occurred when high $\mathrm{CO}_{3}$ tension was added to the low oxygen tension. No inhibition was noted when the cells were exposed to high carbon dioxide and normal oxygen tension.

Microbicidal activity. The killing of L.monocytogenes by alveolar macrophages, polymorphonuclear leukocytes,

\section{PHAGOCYTOSIS I DAY} AFTER ISOLATION

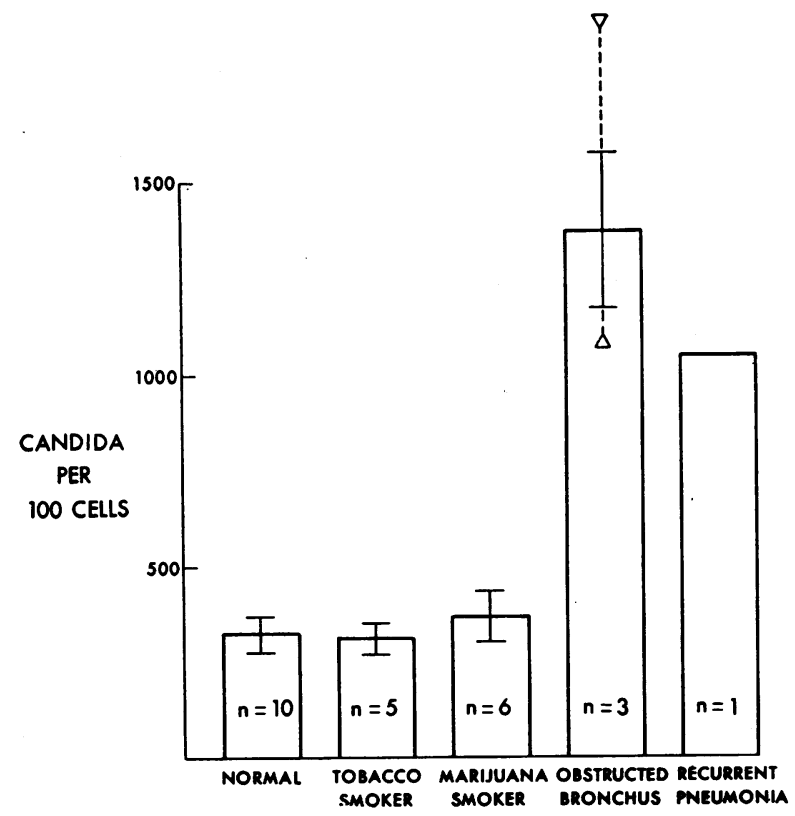

Figure 4 Phagocytosis of $C$. albicans by alveolar macrophages from normal (nonsmoking), tobacco smoking, and marijuana smoking subjects, and patients with postobstructive or lipoid pneumonia $24 \mathrm{hr}$ after isolation. Tubes of cells were incubated, in duplicate, with $10^{7}$ heat-killed $C$. albicans blastospores for $15 \mathrm{~min}$. Vertical broken line indicates range. Vertical solid line indicates standard error. $n$ is the number of subjects.

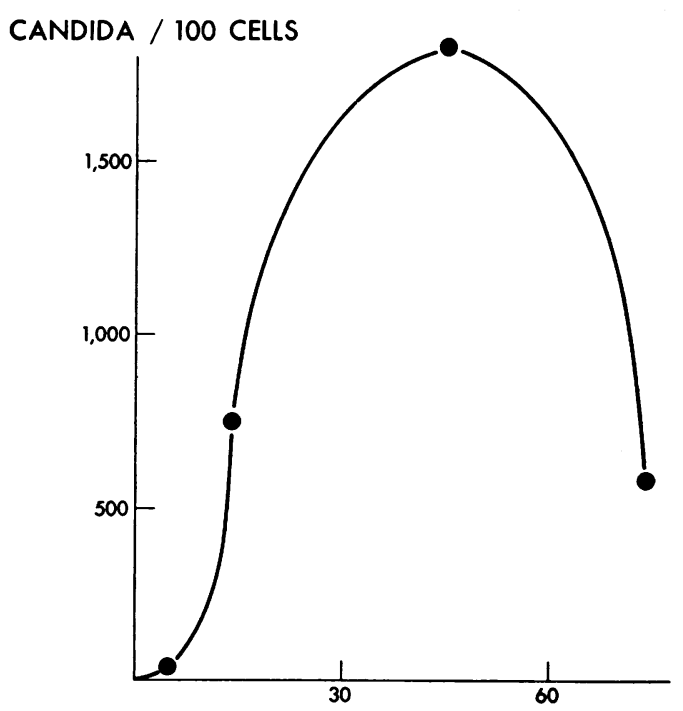

MINUTES AFTER ONSET OF PHAGOCYTOSIS

FIgURE 5 Phagocytosis of $C$. albicans by 4-day-old alveolar macrophages. Maximum particle ingestion at $45 \mathrm{~min}$ was followed by a decline. Cells were incubated, in duplicate, with $10^{7}$ heat-killed $C$. albicans blastospores and tested at the intervals shown. Similar curves were obtained when $A$. fumigatus was used as the test particle or when older or younger cells were tested.

and monocyte-derived macrophages is shown in Fig. 6. Within $1 \frac{1}{2} \mathrm{hr}$ after the onset of phagocytosis, alveolar macrophages killed $64 \%$ of ingested $L$. monocytogenes, whereas polymorphonuclear leukocytes killed $98 \%$. Killing of $L$. monocytogenes by alveolar macrophages was nearly complete within the first $5 \mathrm{hr}$. Macrophages derived from monocytes resembled alveolar macrophages in their ability to kill $L$. monocytogenes. In similar studies, $K$. pneumoniae were eliminated from all three groups of cells within $1 \frac{1}{2} \mathrm{hr}$. Electron micrographs of phagocytized bacteria showed electron-dense granules at the periphery of the phagosomes within the phagosomal membrane. This observation suggests that degranulation of lysosomes into phagosomes occurs in alveolar macrophages as it does in other phagocytic cells. In contrast to their ability to kill $L$. monocytogenes and $K$. pneumoniae, we were unable to detect killing of ingested C. albicans during periods of observation up to $4 \mathrm{hr}$.

\section{DISCUSSION}

Until recently the alveolar macrophage has been inaccessible for study in man. Retrieval of macrophages from awake subjects has three major drawbacks: $(a)$ The number of cells recovered is small; $(b)$ The cells survive poorly in suspension cultures, precluding long-term studies; and (c) Only lungs from subjects with normal pulmonary function can be lavaged safely. We over- 
TABLE II

Effects of Metabolic Inhibitors on Phagocytosis by Alveolar Macrophages*

\begin{tabular}{llll}
\hline $\begin{array}{c}\text { Metabolic } \\
\text { inhibitor } \\
\text { of }\end{array}$ & $\begin{array}{c}\text { Inhibitor } \\
\text { (concentration) }\end{array}$ & $\begin{array}{c}\text { Mean } \\
\text { per cent } \\
\text { inhibition }\end{array}$ & $P \ddagger$ \\
\hline Glycolysis & $\begin{array}{c}\text { Sodium iodoacetate } \\
\left(1 \times 10^{-4} \mathrm{M}\right)\end{array}$ & 50.6 & $<0.001$ \\
Glycolysis & $\begin{array}{c}\text { Sodium fluoride } \\
\left(2 \times 10^{-3} \mathrm{M}\right)\end{array}$ & 25.7 & $<0.025$ \\
$\begin{array}{c}\text { Potassium cyanide } \\
\left(1 \times 10^{-3} \mathrm{M}\right)\end{array}$ & 19.7 & $<0.025$ \\
$\begin{array}{c}\text { Oxtochrome electron } \\
\text { transport }\end{array}$ & $\begin{array}{c}\text { Dinitrophenol } \\
\left(2 \times 10^{-4} \mathrm{M}\right)\end{array}$ & 9.1 & $>0.10$ \\
$\begin{array}{c}\text { Oxidative metabolism } \\
\text { Nitrogen } \\
(100 \%)\end{array}$ & 39.8 & $<0.02$ \\
\hline
\end{tabular}

* Cells incubated with inhibitor for $1 \mathrm{hr}$ before adding $C$. albicans. Phagocytosis examined $15 \mathrm{~min}$ after adding $C$. albicans.

† Probability estimated by Student's " $t$ " test for matched controls.

came these problems by developing the method for lavaging large numbers of alveolar macrophages from surgically resected human lungs. Surgical specimens can be obtained from patients with a number of diseases; however, normal macrophages can also be retrieved from resected lungs. Cells obtained from lungs of patients with endobronchial tumors function normally, as judged by the tests we employed, unless the cells are recovered from areas of lung distal to an obstructed bronchus. As the cells age in vitro their size and phagocytic capacity increase and after 3-4 wk they develop increased numbers of nuclei and vacuoles.

The multinucleated giant cells observed after several weeks in tissue culture had as great as a 30 -fold increase in phagocytic capacity over the capacity of the same group of cells observed on the 1st day after isolation.

In addition, serum containing precipitating and skinsensitizing antibody to $A$. fumigatus augmented phagocytosis of heat-killed $A$. fumigatus but not of $C$. albicans. Whether this is a clinically important factor in allergic

TABLE III

Effects of Gas Tension on Phagocytosis*

\begin{tabular}{|c|c|c|c|}
\hline \multicolumn{2}{|c|}{ Gas environment } & \multirow{2}{*}{$\begin{array}{l}\text { Mean per cent } \\
\text { inhibition }\end{array}$} & \multirow[b]{2}{*}{$P \ddagger$} \\
\hline $\mathrm{PCO}_{2}$ & Po: & & \\
\hline \multicolumn{2}{|c|}{$m m \mathrm{Hg}$} & & \\
\hline 40 & 25 & 39.3 & $<0.005$ \\
\hline 70 & 25 & 38.4 & $<0.01$ \\
\hline 70 & 140 & -15.4 & $>0.50$ \\
\hline
\end{tabular}

* Cells incubated with gas for $1 \mathrm{hr}$ before adding C. albicans. Phagocytosis examined $30 \mathrm{~min}$ after adding $C$. albicans.

$\ddagger$ Probability estimated by Student's $t$ test for matched controls. lung diseases such as allergic aspergillosis has not been determined.

To determine which metabolic pathways provide energy for phagocytosis, we added metabolic inhibitors to macrophages and found that phagocytosis is partially inhibited by iodoacetate, sodium fluoride, potassium cyanide, and nitrogen atmosphere. Other investigators have published conflicting views regarding the effects of metabolic inhibitors on phagocytosis by animal alveolar macrophages. Oren, Farnham, Kazuhisa, Milofsky, and Karnovsky (16) found a similar pattern of phagocytosis inhibition in alveolar macrophages from guinea pigs. Ouchi, Selvaraj, and Sbarra (17), however, found that only anoxia and concentrations of cyanide that caused the cells to take up trypan blue from the medium (i.e., levels which killed the cells) inhibited phagocytosis by rabbit alveolar macrophages. These investigators further argued that the levels of iodoacetate used by Oren et al. (16) to inhibit glycolysis also inhibited oxidative metabolism. To avoid such criticisms of our experiments, we demonstrated that the concentration of cyanide used in the experiments did not cause the cells to take up trypan blue after $2 \mathrm{hr}$ of exposure and that the levels of iodoacetate used did not change oxygen consumption.

Certain pathologic states were also shown to be associated with abnormal macrophage function. Macrophages from patients with tumors that obstruct a bronchus and from one patient with recurrent bacterial pneumonia had supernormal capacity to ingest particles. We believe that these observations indicate that diseases probably exist in which altered macrophage function may be a part of the disease state.

In our experiments macrophages from smokers had normal phagocytic capacity, and Harris, Swenson, and

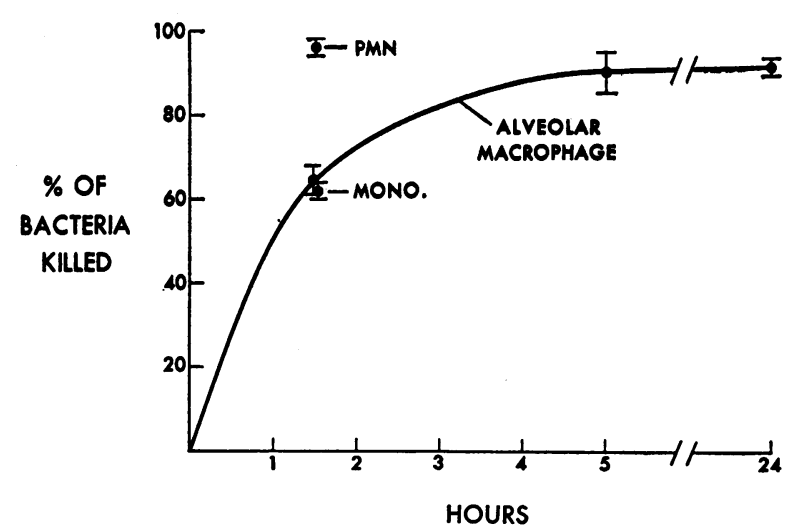

FIGURE 6 Ability of alveolar macrophages, polymorphonuclear leukocytes (PMN) and monocyte-derived macrophages (mono) to kill L. monocytogenes. Observations of PMN and mono killing were made only at $1 \frac{1}{2} \mathrm{hr}$. 
Johnson (5) found no difference in bacterial killing by macrophages from smokers and from nonsmokers. Green and Carolin (18), however, have shown that the ability of rabbit alveolar macrophages to kill bacteria in vitro is inhibited by very high concentrations of cirgarette smoke.

After phagocytosis, the second important function of the alveolar macrophage is killing of microorganisms. Our comparative studies of the efficiency with which alveolar macrophages, neutrophils, and monocyte-derived macrophages kill $L$. monocytogenes and $K$. pneumoniae showed that alveolar macrophages resemble macrophages derived from monocytes in their ability to kill bacteria. Both cell types fail to stain with histochemical stains for peroxidase. Klebanoff (19) showed that bactericidal activity of neutrophils is probably partially dependent upon myeloperoxidase. Lehrer, Hanifin, and Cline (20) confirmed that observations by showing that neutrophils from a patient with hereditary myeloperoxidase deficiency had subnormal bacterial killing ability. The microbicidal mechanisms of the human alveolar macrophage are independent of peroxidase but may involve a catalase-dependent mechanism. Gee, Vassallo, Bell, Kaskin, Basford, and Field (21) have shown that catalase-related $\mathrm{H}_{2} \mathrm{O}_{2}$ metabolism does occur in rabbit alveolar macrophages.

In order to determine how alveolar macrophages function under conditions that may prevail in diseased lungs, we performed experiments on the effect of the gas environment on phagocytosis. Since an arterial $\mathrm{P}_{o_{2}}$ of about $25 \mathrm{~mm} \mathrm{Hg}$ is the lowest compatible with brain viability (22), it is reasonable to assume that some alveolar macrophages exist at this oxygen tension, or lower, in patients with severe chronic bronchitis and emphysema or atelectasis. We found that an oxygen tension as high as $25 \mathrm{~mm} \mathrm{Hg}$ still had a suppressive effect on phagocytosis. Therefore, macrophages probably function suboptimally in areas of the lung in which oxygen tensions are greatly decreased. In contrast, carbon dioxide tensions as high as $70 \mathrm{~mm} \mathrm{Hg}$ did not affect particle uptake as long as $\mathrm{pH}$ was held constant. Unlike other leukocytes, the human alveolar macrophage is therefore highly dependent upon oxidative metabolism for optimal phagocytic activity. These observations suggest that the predisposition of patients with atelectasis (23) or with severe chronic bronchitis and emphysema (24) to pulmonary infection may be related to the suppressive effect of localized hypoxia on alveolar macrophage function. Defense of the lungs by alveolar macrophages is probably most impotrant in these patients because they have impaired bronchial clearance and infected lower respiratory trees.

\section{ACKNOWLEDGMENTS}

We are grateful to Dr. R. Gardner, French Hospital, San Francisco, for allowing us to lavage the lungs which he resected; to Dr. T. Finley, Mt. Zion Hospital, San Francisco, for allowing us to share the alveolar macrophages recovered from normal volunteers; to Dr. J. Lee, University of California, San Francisco, for preparing and examining the electron micrographs; and to Dr. R. Lehrer, University of California, San Francisco, for performing the candidacidal experiments. We also wish to thank Dr. R. Lehrer and Dr. S. Salmon for reviewing the manuscript, and Miss J. Weston for technical assistance.

This work was supported by U. S. Public Health Service Grants HE 5705, HE 5251, CA 07723, and CA 11067, the A. L. Hobson Memorial Fund, the Rose Tornberg Fund, the Avery Cancer Research Fund, and the Cancer Research funds of the University of California.

\section{REFERENCES}

1. Laurenzi, G. A., L. Berman, M. First, and E. H. Kass. 1964. A quantitative study of the deposition and clearance of bacteria in the murine lung. J. Clin. Invest. 43: 759.

2. Green, G. M., and E. H. Kass. 1964. The role of the alveolar macrophage in the clearance of bacteria from the lung. J. Exp. Med. 119: 167.

3. Green, L. H., and G. M. Green. 1968. Differential suppression of pulmonary antibacterial activity as the mechanism of selection of a pathogen in mixed bacterial infection of the lung. Amer. Rev. Resp. Dis. 98: 819.

4. Kass, E. H., G. M. Green, and E. Goldstein. 1966. Mechanisms of antibacterial action in the respiratory system. Bacteriol. Rev. 30: 488.

5. Harris, J. O., E. W. Swenson, and J. E. Johnson. 1970. Phagocytic ability and glucose utilization of alveolar macrophages in smokers and nonsmokers. Clin. Res. 18: 146. (Abstr.)

6. Myrvik, Q. N., E. S. Leake, and B. Fariss. 1961. Studies on pulmonary alveolar macrophages from the normal rabbit: A technique to procure them in a high state of purity. J. Immunol. 86: 128.

7. Voisin, C., J. Guillaume, C. Van-Moorleghem, and C. Aerts. 1963. Sélection et mise en survie in vitro des macrophages alvéolaires de cobaye. Aspects morphologiques et cinétiques, activités métaboliques et phagocytaires. Ann. Inst. Pasteur Lille. 14: 183.

8. Finley, T. N., E. W. Swenson, W. S. Curran, G. L. Huber, and A. J. Ladman. 1967. Bronchopulmonary lavage in normal subjects and patients with obstructive lung disease. Ann. Intern. Med. 66: 651.

9. Pratt, S. A., T. N. Finley, M. H. Smith, and A. J. Ladman. 1969. A comparison of alveolar macrophages and pulmonary surfactant (?) obtained from the lungs of human smokers and nonsmokers by endobronchial lavage. Anat. Rec. 163: 497.

10. Beacom, D. N. 1926. Modification of Goodpasture's technique for the peroxidase reaction in blood smears. J. Lab. Clin. Med. 11: 1092.

11. Lee, J. C., G. M. Grodsky, J. Caplan, and L. Craw. 1969. Experimental immune diabetes in the rabbit. Light, fluorescence and electron microscopic studies. Amer. J. Pathol. 57: 597.

12. Firket, H. 1966. Polyester sheeting (Melinex O), a tissue-culture support easily separable from epoxy resins after flat-face embedding. Stain Technol. 41: 189. 
13. Cline, M. J. 1970. Bactericidal activity of human macrophages: analysis of factors influencing the killing of Listeria monocytogenes. Infection and Immunity. 2: 156.

14. Lehrer, R. I., and M. J. Cline. 1969. Interaction of Candida albicans with human leukocytes in serum. $J$. Bacteriol. 98: 096.

15. Lehrer, R. I. Measurement of candidacidal activity of specific leukocyte types in mixed cell populations, I. Normal, myeloperoxidase-deficient, and chronic granulomatous disease neutrophils. Infection and Immunity. 2: 42 .

16. Oren, R., A. E. Farnham, K. Saito, E. Milofsky, and M. L. Karnovsky. 1963. Metabolic patterns in three types of phagocytizing cells. J. Cell Biol. 17: 487.

17. Ouchi, E., R. J. Selvaraj, and A. J. Sbarra. 1965. The biochemical activities of rabbit alveolar macrophages during phagocytosis. Exp. Cell. Res. 40: 456.

18. Green, G. M., and D. Carolin. 1967. The depressant effect of cigarette smoke on the in vitro antibacterial ac- tivity of alveolar macrophages. N. Engl. J. Med. 276: 421.

19. Klebanoff, S. J. 1967. Iodination of bacteria: a bactericidal mechanism. J. Exp. Med. 126: 1063.

20. Lehrer, R. I., J. Hanifin, and M. J. Cline. 1969. Defective bactericidal activity in myeloperoxidase-deficient human neutrophils. Nature (London). 223: 78.

21. Gee, J. B. L., C. L. Vassallo, P. Bell, J. Kaskin, R. E. Basford, and J. B. Field. 1970. Catalase-dependent peroxidative metabolism in the alveolar macrophage during phagocytosis. J. Clin. Invest. 49: 1280.

22. Nunn, J. F. 1969. Applied Respiratory Physiology. Butterworth \& Co., Ltd., London. 361.

23. Ziskind, M. M., M. I. Schwarz, R. B. George, H. Weill, J. M. Shames, S. J. Herbert, and H. Ichinose. 1970. Incomplete consolidation in pneumococcal lobar pneumonia complicating pulmonary emphysema. Ann. Intern. Med. 72: 835

24. Spencer, H. 1968. Pathology of the Lung. Pergamon Press, Inc., New York, 2nd edition. 508. 